\title{
Bronze Age Subsistence Change at Regional and Microscopic Scales in Northeast China
}

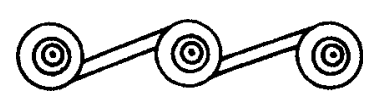

James T. Williams

\begin{abstract}
This article investigates Late Bronze Age mobile pastoralism in Northeast China. Analysis of the use-wear patterns provides direct evidence speaking to the subsistence economies during the Bronze Age. The patterns of use-wear are compared to the settlement patterning and environmental contexts to test proposed theories about whether and how subsistence change takes place. The results indicate continuity in mixed animal and plant based economies in both the Early and Late Bronze Age despite changes in climate and population. The relative intensity of economic practice is guided by the environmental context, but this is detected only at the sub-regional level. Keywords: subsistence economy, pastoralism, use-wear, Bronze Age, Northeast China.
\end{abstract}

\section{INTRODUCTION}

THE EMERGENCE OF SPECIALIZED MOBILE HERDiNG HAS LONG BEEN THOUght TO HAVE taken place in Northeast China during the Late Bronze Age (1200-600 B.C.e.) (DiCosmo 2002). It is theorized that the interaction between specialized herders and sedentary farmers was the catalyst for increased social complexity in the region (DiCosmo 2002; Lattimore 1940; Linduff 1995, 1997; Shelach 1999). However, in Northeast China there is little direct settlement and subsistence evidence indicating the emergence of mobile pastoralism or specialized mobile herding. In direct contrast, there is mounting evidence for either sedentary farmers (Chifeng 2011) or agropastoralists with ideational connections to the steppe regions who engaged macro-regionally in a variety of subsistence economies throughout the Early and Late Bronze Age (Shelach 2009). Therefore, theories based on assumed interaction between specialized herders and farmers in Northeast China remain untested.

Following the pioneering work of Lees and Bates (1974), the concept that specialized nomadic pastoralism was adopted and prospered tethered to farmers is not unique to Northeast China. Many researchers suggest an interdependent or dependent relationship between groups of local communities specializing in herding and other specialized farmers as a general principle (Barfield 2001; Irons 1979; Jagchid and Symons 1989; Kazanov 1994). Furthermore, many theorists have proposed that climate change at about 1200 B.C.E. (Li et al. 2006; Su and Zhao 2003; Tarasov et al.

James T. Williams is an Assistant Professor of Archaeology in the Department of Archaeology and Museum Studies, School of History, Renmin University of China. 
2006; Wagner et al. 2013; Wagner et al. 2011; Wanner et al. 2008; Zhang et al. 2005) became the catalyst for this change in subsistence economy (An et al. 2004; Huang et al. 2003; Jin and Liu 2002; Liu and Feng 2012; Wu and Liu 2004; Xiao et al. 2004). Unfortunately, many of these attempts at economic reconstruction rely either on bronze style or counting sites documented in the Chinese national heritage survey (e.g., Liu and Feng 2012). Bronze style may indicate some cultural continuity with steppe groups (Shelach 2009), but should not be used as a proxy for economic practice (Lin 2002). Site counts from national registries may be misleading or outright inappropriate for reconstructing social or economic organization (Drennan et al. 2015:131-133).

In light of this gap in our knowledge, this research is designed to address two issues:

1. Did reliance on grazing animals and residential mobility increase during the Late Bronze Age?

2. Were nomadic pastoralists located in areas where such subsistence strategies would have been attractive alternatives to grain cultivation?

In other words, can evidence of subsistence specialization be detected through stone tool analysis for multiple communities in Northeast China where it has been previously theorized? Addressing this issue requires no doubt taking into consideration multiple lines of evidence. The present article focuses on use-wear evidence to make tentative conclusions and related hypotheses.

This article investigates changes in stone tool assemblages and use-wear from the Early Bronze Age (2000-1200 B.C.E.) to Late Bronze Age (1200-600 B.C.E.) in Zhangwu County, Liaoning $\left(42^{\circ} 37^{\prime} \mathrm{N}, 122^{\circ} 43^{\prime} \mathrm{E}\right)$ (Figs. 1-4). While the two Bronze Age periods are the most relevant to the research agenda, Hongshan (4500-3000 B.C.E.), Iron Age (Zhanguo-Han Period) (600 B.C.E.-200 C.E.) (Williams 2015), and Liao Period (200-1200 C.E.) ceramics were also recovered. Surveyors covered the landscape at $50 \mathrm{~m}$ spacing and collected ancient sherds were encountered. Overall, roughly 18,000 ancient sherds were recovered from this full coverage, systematic

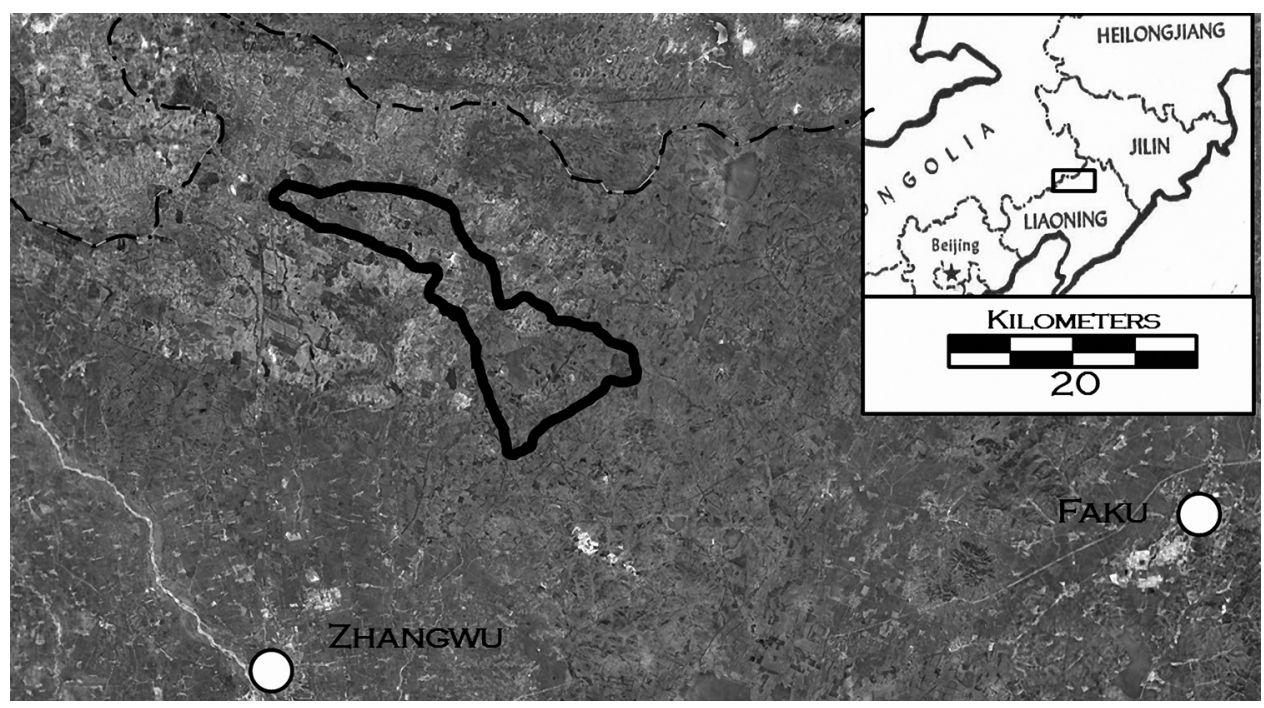

Fig. 1. Research area. 

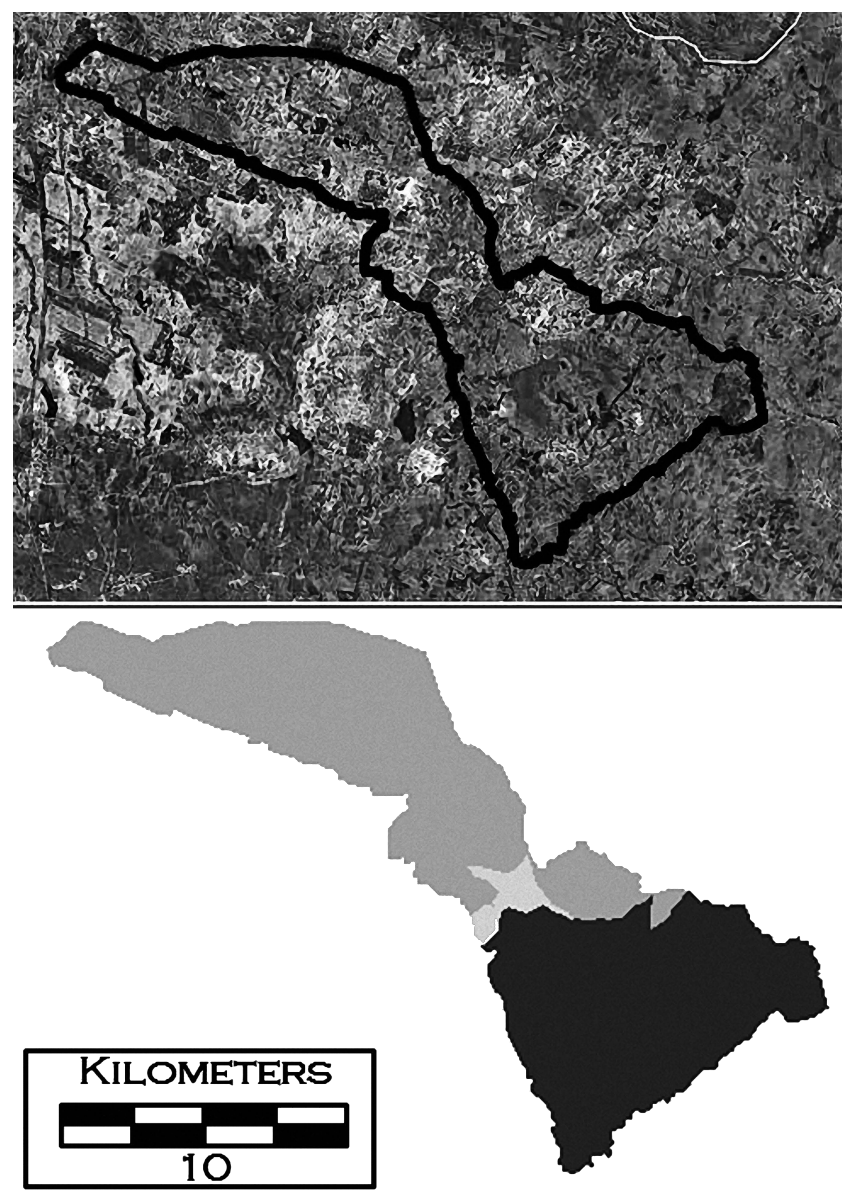

Fig. 2. Northern and southern subregions. Lighter area indicates an intermediate area that has been modified significantly in recent history.

regional survey. During this fieldwork, 550 lithics were also recovered. The research area covered $173 \mathrm{~km}^{2}$ and was chosen because of its environmental variability. Based on the environmental characteristics, including different soil regimes, Normalized Difference Vegetation Index (NDVI), water tables, and geophysical characteristics (Boerma et al. 1995a, 1995b), the survey area was divided into northern and southern subregions (Williams 2014) (Fig. 2).

The predominant variables that were used to divide the region were NDVI values from 1986 and modern land use patterns. These are largely contingent on the soil quality in these regions. The northern and southern subregions are clearly visible from satellite imagery, but this is a reflection of the underlying differences in soil quality resulting in different vegetation (Fig. 2). The overall environment in the recent past certainly differs from the Bronze Age. However, there would have been differences between the two subregions in the past because it would have taken thousands of years for soil genesis to occur in each zone. The northern part of the survey area might have been grassier during the Bronze Age and the southern part might have been more 
wooded than current conditions. The region would have remained an ecotone, although the characteristics of that ecotone may have shifted.

If the environmentally contingent models mentioned above bear out in local contexts, then each subregion should have different proportions of stone tool evidence. Evidence of economic differences between the two subregions would be informative as to how the environment might have affected the theorized change from farming communities to a landscape dominated by herders in a region that has the environmental diversity to support both of these economies.

\section{COMMUNITY SPECIALIZATION}

The settlement evidence from regional survey in Zhangwu indicates a major shift in the patterning of human habitation from the Early to the Late Bronze Age. The settlement pattern shifts from a landscape scattered throughout with large, dense settlements (500-2000 people), medium-sized settlements (100-500 people), and small settlements (less than 100 people) to a landscape containing a single large settlement (Tuchengzi) and a number of smaller sites. The Early Bronze Age pattern is similar to what has been observed in other nearby regions (Chifeng 2011). However, the shift in settlement pattern by the Late Bronze Age is unique to Zhangwu. The most conspicuous element of this shift is a dramatic decrease in the regional population. Besides depopulation, people shifted from a tendency to live in both the north and southern subregions of the survey area in the Early Bronze Age to more occupation areas in the northern subregion in the Late Bronze Age (Figs. 3, 4).

These differences alone might suggest that there was a shift in economic practices during the Bronze Age. However, decline alone is not enough to support this argument. A decline in population to levels, which are analogous to ethnographic mobile herders must be established. In addition, there was no strong tendency to favor grassland soils or fertile farm soils in either period. The evidence from artifact distribution and lithic use-wear presented here therefore addresses economic practices directly to understand the economic nature of this demographic shift should it exist.

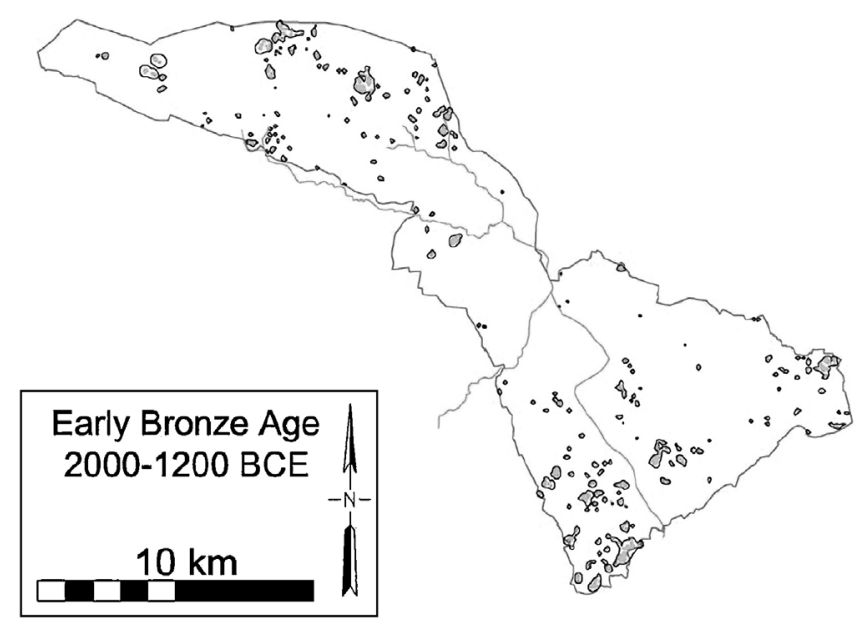

Fig. 3. Early Bronze Age settlement pattern. 


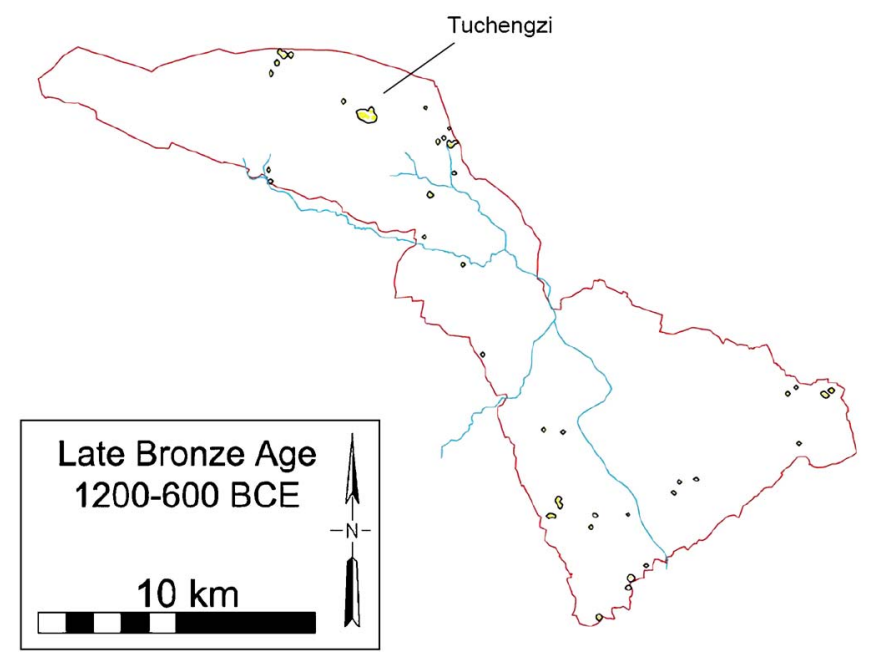

Fig. 4. Late Bronze Age settlement pattern.

A number of survey collection units that included stone tools and/or ceramic spindle whorls were selected for analysis. In addition to examining diachronic change, lithic analysis and use-wear evidence is intended to show whether there was a difference in economic practices between the northern and southern subregions during the Bronze Age.

The "local community," a collection of households that would have interacted daily (Flannery 1976; Murdock 1949), is the smallest economic unit that this research is equipped to discuss in terms of economic differentiation or specialization. In order to best understand household or intra-settlement differentiation, one would need to carry out additional fieldwork, including smaller-scale surface collection and excavation. Faunal and paleobotanical analyses from secure household contexts would certainly aid in this endeavor. However, these studies are generally smaller than the analytical units (communities and multiple communities) that could evaluate economic shifts over large areas theorized in the models discussed above. Therefore, lithic tools were grouped together and organized by "local communities" delimited by the methods described by Peterson and Drennan (2005) and Williams (2014). The designation of each local community is in some way analogous to what archaeologists refer to as "sites," but avoids some of the pitfalls of determining discrete "sites" (Banning 2002:14-17).

The methodology for determining the populations of these communities is described in detail in other publications (Chifeng 2011; Drennan et al. 2015). However, broadly speaking, these estimates are based on the size and density of ceramic collections, and then divided by the length of a particular period (to account for accumulation of archaeological materials over different archaeological periods). The raw data for establishing a correlation between site size with ceramic density and population come from analysis of modern occupation areas as well as surface archaeology and the underlying household material among several Neolithic and Bronze Age settlements (Chifeng 2011). Although the estimates presented below may appear exact, they carry error ranges of about half the median population figures. That said, for the purposes of this article, these population estimates allow us to divide the 
local communities into rough categories of small, medium, or large. Since low population density is nearly always correlated with mobile herding (Murdock and Wilson 1972), this categorization would allow us to establish any correlation that might exist between economic practices (indicated by the stone tool analysis) and community size. Therefore, it establishes in real human numbers the intensity of the Bronze Age population decline.

The economic complementarity models described by Linduff $(1995,1997)$ and Shelach (1999) suggest that much larger populations (larger than individual households and communities) engage in the exchange of products. According to these models, entire local communities would have been altering their economic practices during the Bronze Age across large regions. These models go on to suggest that subsistence specialization by entire communities would be conspicuous across multiple communities by the Late Bronze Age and be coupled with an increase in residential mobility. At this point, any specialized mobile communities would acquire agricultural products primarily through exchange with specialized sedentary agricultural communities or by raiding such communities (Barfield 1989, 2001; DiCosmo 1994, 1999).

The following stone tool analysis, conducted at a scale, which includes multiple communities across different environments, provides the type of evidence to test notions of economic change that would support claims mentioned above. The stone tool evidence, especially use-wear analysis, is meant to supplement other forms of data such as settlement data. However, these data stand alone as evidence in a larger argument about subsistence economic shifts or persistence in the subsistence economy. Finally, establishing a finer point on economic practice through stone tool analysis moves interpretation away from false dichotomies about herders and farmers, since both ends of the subsistence spectrum may theoretically and practically exist at the same time.

\section{METHODS}

Sampling Strategy and Macroscopic Lithic Analysis

The use-wear analysis was carried out at the Liaoning Provincial Institute of Archaeology in early July 2012. As mentioned above, 550 lithics were recovered from over 2000 collection lots during a regional survey (Williams 2014). Of these, 122 lithic artifacts were from single-component sites yielding either Early or Late Bronze Age ceramics; these were selected for microscopic investigation. Selecting the lithics from single-component settlements mitigates the problem that lithics from surface collections taken from multi-component sites are difficult to assign to a particular period. Each lithic was scanned for approximately 15-30 min. The vast majority of these tools showed no clear indication of use-wear. However, 39 tools provided evidence of 42 instances of use-wear (three tools appear to have use-wear evidence in multiple locations on the tool).

All chipped stone tools were analyzed macroscopically and typologized according to the categories described in Table 1. A complete piece of debitage or tool was not necessary to make the following determinations as long as the specimen exhibited the defining properties. In other words, what some scholars define as flake fragments or blade fragments are categorized here as flakes and blades. 
Table i. Stone Tool Classification

\begin{tabular}{|c|c|}
\hline Shatter & $\begin{array}{l}\text { Angular debitage without a clear bulb of percussion and blocky in } \\
\text { form }\end{array}$ \\
\hline Primary flake & A flake with a clear bulb of percussion and cortex \\
\hline Secondary flake & A flake with a clear bulb of percussion and no cortex \\
\hline Complex flake & A flake with a clear bulb of percussion and thinning flake removals \\
\hline Blade & $\begin{array}{l}\text { An elongated flake with parallel margins; this category includes } \\
\text { microblades }\end{array}$ \\
\hline Core & Stones in which flakes are removed in one or more direction \\
\hline Bullet core & A formal unidirectional core for the creation of microblades \\
\hline Formal tool & Any stone tool artifact with a macroscopically clear function \\
\hline \multicolumn{2}{|l|}{ Formal tool types } \\
\hline Awl/drill & $\begin{array}{l}\text { A tool with a point extending from a shouldered body; } \\
\text { macroscopic micro-chipping usually found on the bit end }\end{array}$ \\
\hline Axe/hoe & $\begin{array}{l}\text { Either chipped or ground elongated stone tools generally larger } \\
\text { than } 15 \mathrm{~cm}\end{array}$ \\
\hline Bifacial point & A bifacially worked point triangular in shape \\
\hline Groundstone knife & An edged implement sometimes with holes on the non-edged side \\
\hline Quernstone & A flat or slightly concave grinding stone \\
\hline Scraper & $\begin{array}{l}\text { A tool with a blunted and slightly rounded edge; characterized by } \\
\text { an edge with retouch removals resulting in a less acute angle. } \\
\text { The most common forms are small "thumbnail" types }\end{array}$ \\
\hline
\end{tabular}

All lithic artifacts were examined microscopically for striations, polishes, microchipping, and other evidence of use-wear. Some archaeologists consider use-wear analysis of lithic artifacts collected from the surface as risky (Knudson 1979; Nash 1993). Since damage from trampling or farm equipment consists of a very specific type of chipping, the use-wear analysis conducted here focuses particularly on striation, rounding, and polish. Furthermore, at the microscopic scale of this use-wear analysis, chipping from use can be distinguished from chipping resulting from taphonomic processes (Odell 2004).

\section{Use-wear Methodology}

A monocular light microscope capable of observing 10, 20, 80, 200, 400, and $800 \times$ magnification was fitted with a 3.5 megapixel video and still camera. The images were displayed in a $13 \mathrm{~cm}$ window on a computer screen using Debut Video Capture Software Professional v1.64. The $13 \mathrm{~cm}$ images displayed on the computer translated to a field of vision $2 \mathrm{~mm}$ wide at $80 \times$ and $0.7 \mathrm{~mm}$ wide at $200 \times$. Magnification here refers to the lenses used, not the actual size of the images. All use-wear images are available in high resolution online. ${ }^{1}$

Artifacts were cleaned using a simple water and detergent mix, rinsed, and let air dry. $^{2}$ The artifacts were scanned at $20 \times$ and/or $80 \times$. The scanning took about 15-30 min per artifact depending on the size. Artifacts were manipulated with tweezers. If an instance of use-wear was located, then a digital photograph was taken at $80 \times$ and sometimes $200 \times$. In addition to basic provenience information, the following characteristics of use-wear were recorded: 


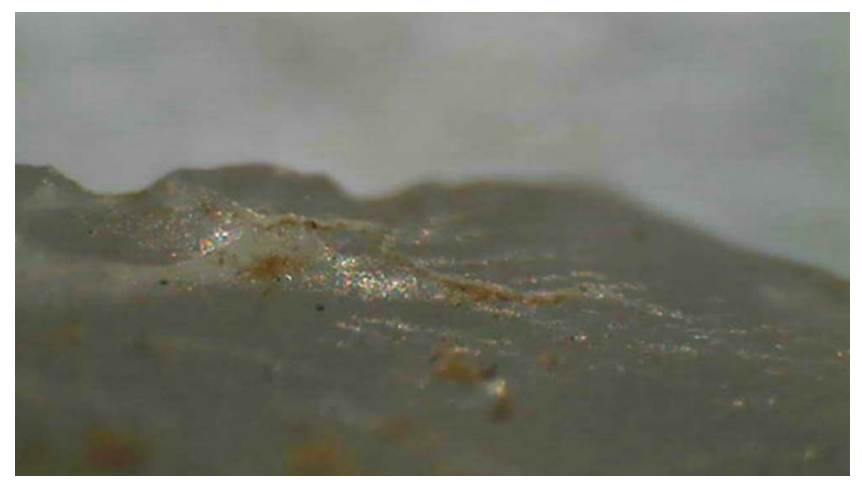

Fig. 5. Example of light longitudinal striations ( $2 \mathrm{~mm}$ wide field of vision).

1. Type of wear: striations (Fig. 5), polish (Fig. 6), rounding (Fig. 7), or micro-chipping (Fig. 8); the type of termination (hinged or feathered) was also recorded for cases of micro-chipping.

2. Direction information: parallel or perpendicular; location of flake termination was recorded for cases of micro-chipping.

3. Location: location of evidence of use-wear on the artifact (Fig. 8).

For the purposes of the research agenda in this article, it was important to determine and distinguish between two types of activities: (1) processing of animals by scraping and (2) cutting agricultural grasses. Clemente and Gibaja (1998) point out that sickles used for cutting cereals show use-wear parallel to the blade edge (Ibáñez et al. 2008). On the other hand, striations that are perpendicular to the tool's edge, also referred to as transverse striations, have been described as indicative of scraping (Lombard 2006; Smallwood 2006).

The two activities most commonly associated with longitudinal use-wear are cutting and sawing. Unidirectional striation vs. multi-directional longitudinal striation distinguishes cutting from sawing. All of the longitudinal striations on the lithics examined for this study are unidirectional, indicating cutting rather than sawing.

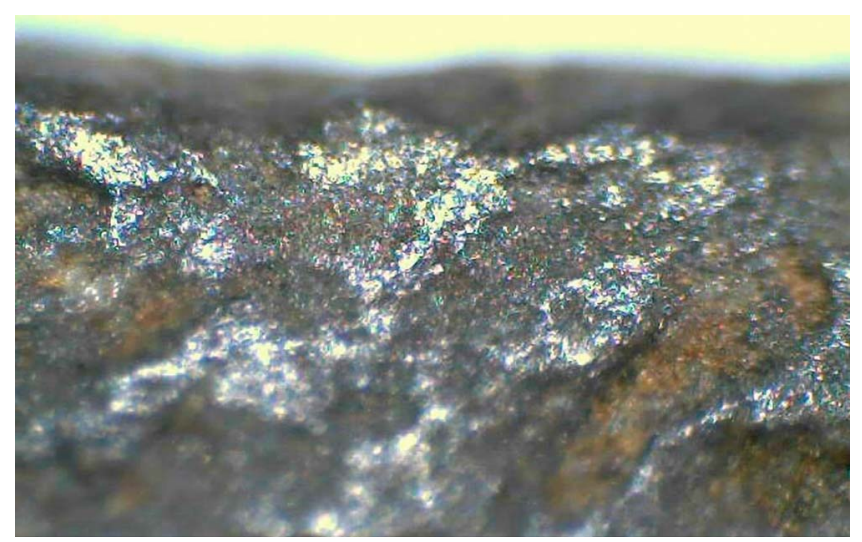

Fig. 6. Example of polish, presumed to be plant polish based on other information $(0.7 \mathrm{~mm}$ wide field of vision). 


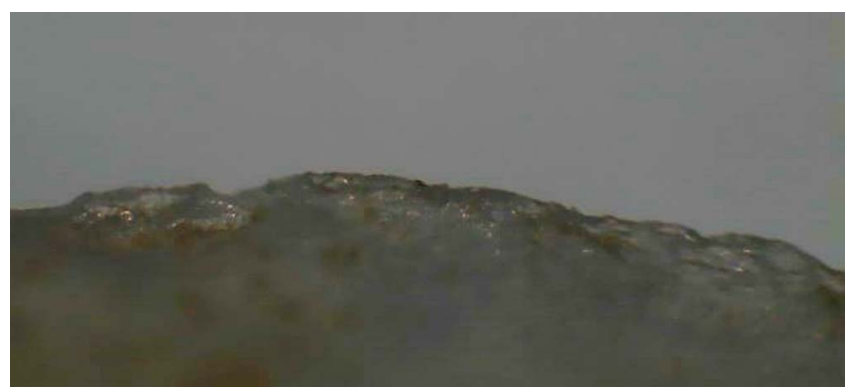

Fig. 7. Example of rounding with no evidence of other use-wear ( $2 \mathrm{~mm}$ wide field of vision).

Polish is found on both animal processing tools and agricultural tools. However, in the case of agricultural tools it is not often found in combination with rounding or micro-chipping. However, polish as a result of scraping of hides and skins is often combined with rounding (Odell 2004:147). Therefore, in those cases where the direction of use-wear was not detectable (no evidence of striation or micro-chipping), the tools with rounding and polish were categorized as scraping tools, while the tools with polish but without rounding were categorized as used for cutting grasses.

Indications of the hardness of a worked material come primarily from the presence or absence of micro-chipping and in the types of flake terminations in those cases where there is evidence of micro-chipping. This follows the methodology detailed by Odell and Odell-Vereecken (1980). They state that using a tool on the hardest materials will produce hinged terminations more often than when used on softer materials, which results in more abundant feathered terminations. Using a tool on even softer materials, such as flesh or soft plant matter, often leaves little evidence of micro-chipping; use-wear instead most often takes the form of light striations and/or polish.

In addition to the methodology described above, use-wear determinations were made by consulting a number of reference images and texts. Gao and Shen (2008) was an especially instrumental resource in making the final use-wear determinations.

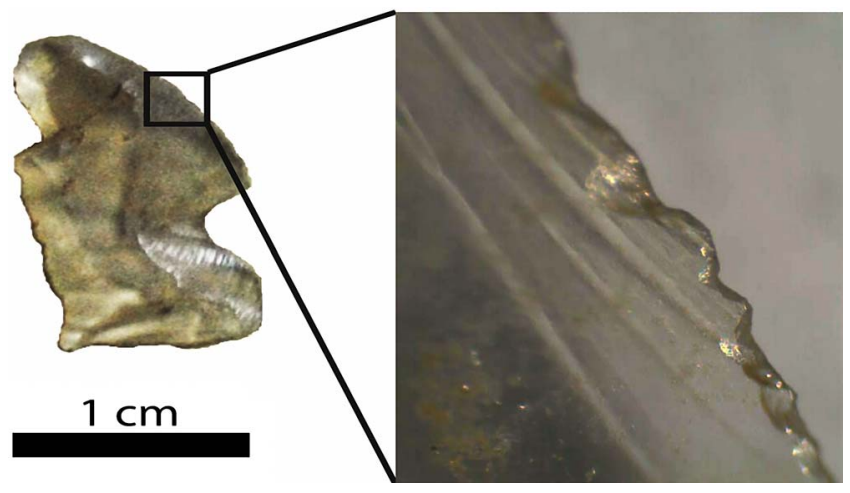

Fig. 8. Example of heavy longitudinal striations and micro-chipping. 

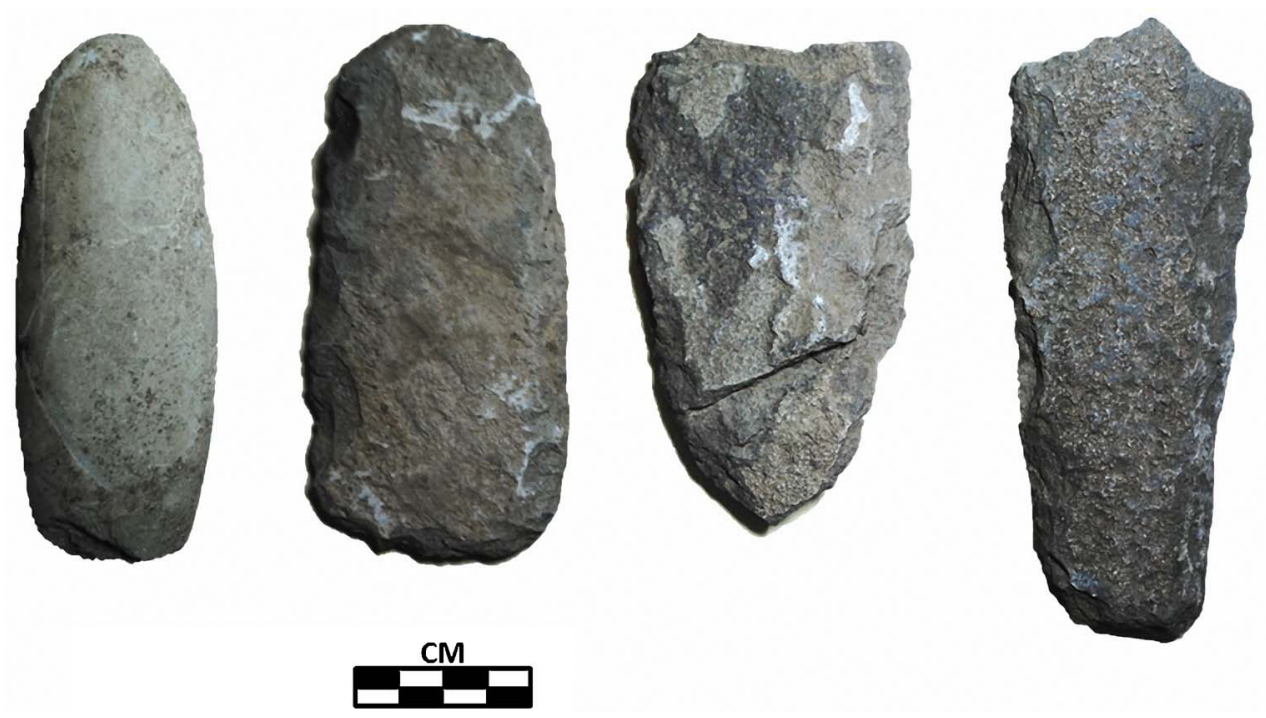

Fig. 9. Stone axes or hoes.

\section{RESULTS AND DISCUSSION}

\section{Artifactual Evidence for Economic Activities}

Agricultural Tools - Axes, hoes, quernstones, and semi-lunar reaping knives are tool types that, when found in greater quantities, are commonly associated with farming during the Early and Late Bronze Age in Northeast Asia (Nelson 1995; Wang 2004, 2007, 2013). Greater proportions of axes and hoes have been associated with land clearing and the intensification of agriculture in Northeast Asia during the Early Bronze Age (Wang 2013:92). Four stone axes were recovered from single-component Bronze Age settlements (Fig. 9, Table 2). All of these are associated with Early Bronze Age settlements from the southern part of the survey area. Three quernstones were also recovered by the survey teams (Table 2). All of these were also found in the southern part of the survey area. One is associated with the Hongshan period, another can be attributed to the Early Bronze Age, and the last quernstone comes from a mixed Early Bronze Age and Liao context.

Table 2. Formal Tool Types Recovered from Bronze Age Settlements

\begin{tabular}{|c|c|c|c|c|c|}
\hline & AXE/HOES & QUERNSTONES & GROUNDSTONE KNIVES & SCRAPER & SPINDLE WHORLS \\
\hline $\begin{array}{c}\text { Early Bronze Age tools, } \\
\text { northern subregion }\end{array}$ & 0 & 0 & 0 & 0 & 1 \\
\hline $\begin{array}{c}\text { Early Bronze Age tools, } \\
\text { southern subregion }\end{array}$ & 4 & 3 & 3 & 0 & 2 \\
\hline $\begin{array}{c}\text { Late Bronze Age tools, } \\
\text { northern subregion }\end{array}$ & 0 & 0 & 1 & 1 & 0 \\
\hline $\begin{array}{l}\text { Late Bronze Age tools, } \\
\text { southern subregion }\end{array}$ & 0 & 0 & 0 & 0 & 0 \\
\hline
\end{tabular}


Groundstone knives or "semi-lunar reaping knives" are commonly associated with the cutting of grains in Northern China and Korea (Nelson 1993, 1995). Four groundstone knives were found at single-component Bronze Age sites, three of which were recovered from the southern part of the survey area. These three agricultural tools are from Early Bronze Age settlements. The final knife was recovered from the northern subregion and dates to the Late Bronze Age. There is little to no scholarly debate about whether or not groundstone knives are primarily used for the cutting of agricultural grasses, but it should be noted that all four had evidence of plant polish and lacked evidence of chipping or striation. It can be presumed that these would have been used for cutting soft plant material such as millet. Several others were found in mixed Early Bronze Age and Liao contexts in the southern subregion (Table 2).

The sickle blade is another common tool associated with the cutting of grains during the Neolithic and Bronze Age in Northeast China. Unfortunately, all of the formal blades found in this survey were either from collections without ceramics or from mixed Hongshan and Early Bronze Age contexts. These were found in both the northern and southern subregions of the survey area.

Tools Related to Animal Economies - Five scrapers as a formal tool type were recovered by the survey team. Four were found in both Neolithic (Hongshan) and Liao contexts; only one of these scrapers from a mixed Early Bronze Age and Liao context was found in the northern subregion of the survey area (Table 2). (Tool use-wear analysis providing evidence of scraping animal hides is examined in detail in the following section.)

Three spindle whorls dated to the Early Bronze Age were found, two from the southern part of the survey area and the other from the northern part. If these tools are related to the production of wool thread from herd animals, then this activity took place in both the southern and northern subregions (Table 2).

Summary - Before examining the microscopic evidence in detail, there already appears to be evidence that a variety of activities related to different types of subsistence took place throughout the survey area. Axes, hoes, groundstone knives, and quernstones seem more abundant in the southern subregion. That said, one groundstone knife was found in the northern subregion, indicating the presence of some agricultural activity. The evidence of sickle blades, scrapers, and spindle whorls suggests that agricultural activities and activities related more to the processing of animals occurred in both northern and southern contexts. Note, however, that the sickle blade and scraper evidence come from mixed contexts and the samples of groundstone knives, scrapers, and spindle whorls are very small. The following usewear analysis provides additional evidence to further investigate any patterning of economic activities specific to the Bronze Age.

\section{Use-wear Evidence of Economic Activities}

A total of 39 lithic artifacts with evidence of use-wear were collected from 17 singlecomponent Early and Late Bronze Age communities of various sizes. Fourteen of the communities were in the northern subregion and three were in the southern part of the survey area (Figs. 10 and 11). Thirty-six tools that produced 39 instances of use-wear were from Early Bronze Age contexts. Three tools can be associated with the Late Bronze Age. 


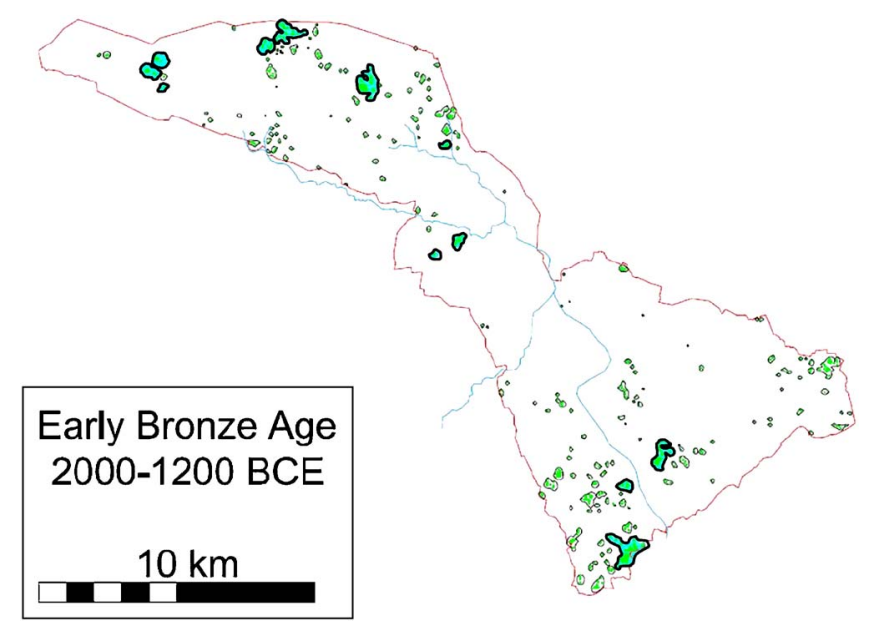

Fig. 10. Early Bronze Age local communities. Single component communities with use-wear evidence in bold.

Several of the tools had indications of use-wear unrelated to either herding or agricultural activities (Table 3). With the exception of the groundstone knives, all the tools in this analysis could be defined as expedient tools (Binford 1973) or utilized flakes, and do not fit into formal tool type designations. The chipped stone tools are made of white, red, or translucent chert. Groundstone knives are made of basalt. Both chert cobbles and basalt are locally available.

A number of stone tools with evidence of use-wear were retrieved from two large settlements in the northern section of the survey area (Table 4). Both of these local

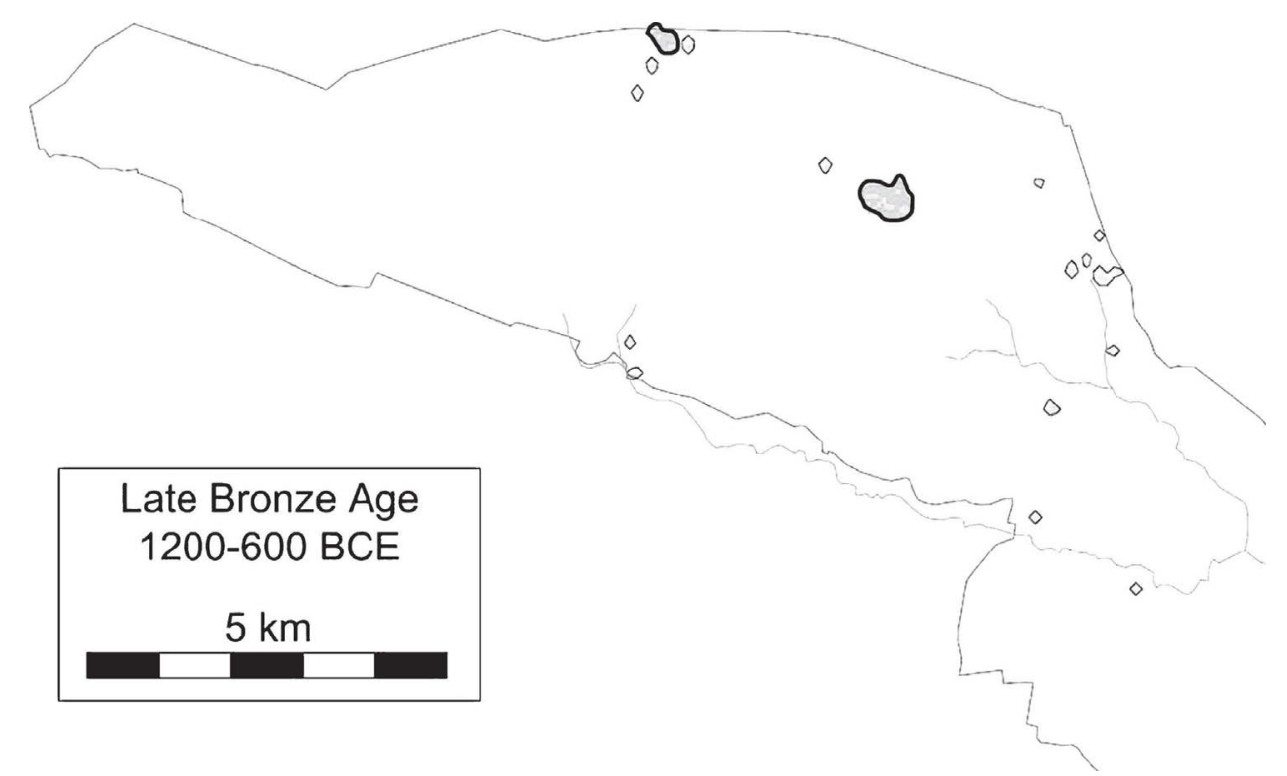

Fig. 11. Late Bronze Age local community delineation in the northern part of the survey area. Communities with use-wear evidence in bold. 
Table 3. Tools, Including Utilized Flakes, with Evidence of Use-Wear

\begin{tabular}{|c|c|c|c|c|c|}
\hline & $\begin{array}{c}\text { \# LOCAL } \\
\text { COMMUNITIES }\end{array}$ & \# TOOLS & PLANT & ANIMAL & $\begin{array}{l}\text { OTHER USE OR } \\
\text { INDETERMINATE }\end{array}$ \\
\hline $\begin{array}{l}\text { Large Early Bronze Age settlements, } \\
\text { northern subregion }\end{array}$ & 3 & 17 & 4 & 8 & 5 \\
\hline $\begin{array}{l}\text { Medium Early Bronze Age settlements, } \\
\text { northern subregion }\end{array}$ & 4 & 5 & 3 & 1 & 1 \\
\hline $\begin{array}{l}\text { Small Early Bronze Age settlements, } \\
\text { northern subregion }\end{array}$ & 2 & 9 & 1 & 7 & 2 \\
\hline $\begin{array}{l}\text { Large Early Bronze Age settlements, } \\
\text { southern subregion }\end{array}$ & 1 & 2 & 2 & 0 & 0 \\
\hline $\begin{array}{l}\text { Medium Early Bronze Age settlements, } \\
\text { southern subregion }\end{array}$ & 1 & 1 & 0 & 1 & 0 \\
\hline $\begin{array}{l}\text { Small Early Bronze Age settlements, } \\
\text { southern subregion }\end{array}$ & 1 & 1 & 1 & 0 & 0 \\
\hline $\begin{array}{l}\text { Large Late Bronze Age settlements, } \\
\text { northern subregion }\end{array}$ & 1 & 2 & 0 & 2 & 0 \\
\hline $\begin{array}{l}\text { Small Late Bronze Age settlements, } \\
\text { northern subregion }\end{array}$ & 1 & 0 & 1 & 0 & 0 \\
\hline
\end{tabular}

communities had estimated populations of around 750 people. In these two communities, the evidence of use-wear presents a picture of varied economic practices. Both of these communities have evidence of cutting plant materials and scraping hides. Most of the evidence from the largest communities indicates high proportions of tools used in processing of animals.

An additional settlement with a population estimate of just over 500 people also yielded use-wear evidence indicating cutting bone, consistent with the butchery of animals. The use-wear of another tool from this local community indicates drilling or piercing. Since an estimated population of 500 is eight to ten times the size of most herding communities (Mearns 1993, 1996), it is very unlikely that such large communities were made up of mobile herding specialists.

Early Bronze Age Use-wear Evidence from the Northern Subregion - The majority of the stone tools with evidence of use-wear come from the northern subregion. The degree to which this area was utilized for agricultural production or animal husbandry can be assessed by looking at the spatial patterning of tools with evidence of wear. The primary types of evidence that address the research question most directly are those that indicate cutting agricultural grasses or scraping hides.

Several medium-sized local communities with estimated populations between 100 and 200 people have evidence of both processing animals and agricultural production (Table 5). The tools found in these communities show evidence of having been used to cut plant materials, scrape animal hides, and butcher animals. We did not find both tool types in any single local community in this size range, however. While this could be interpreted as local community-level economic specialization, it is more likely a result of small sample size.

The nature of economic practices in the north does not seem to be affected by the size of the local communities. One would expect that if there had been a trend toward 
Table 4. Early Bronze Age Use-Wear from Large Local Communities, Northern SUBREGION

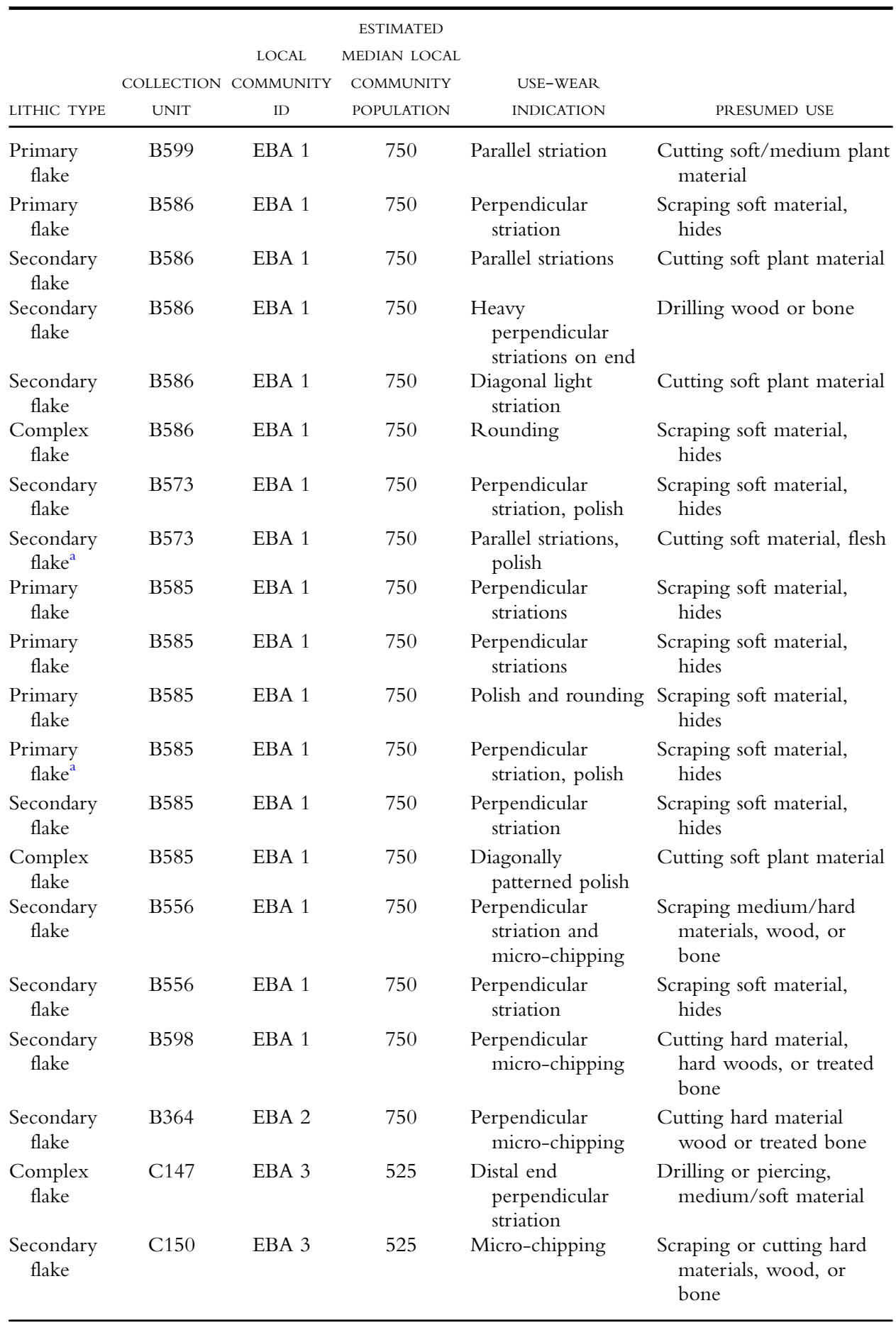

${ }^{\mathrm{a}}$ Same tool as above. 
Table 5. Early Bronze Age Use-wear Evidence from Medium-sized Communities, NORTHERn SUBREgION

\begin{tabular}{|c|c|c|c|c|c|}
\hline LITHIC TYPE & $\begin{array}{c}\text { COLLECTION } \\
\text { UNIT }\end{array}$ & $\begin{array}{c}\text { LOCAL } \\
\text { COMMUNITY } \\
\text { ID }\end{array}$ & $\begin{array}{l}\text { ESTIMATED } \\
\text { MEDIAN LOCAL } \\
\text { COMMUNITY } \\
\text { POPULATION }\end{array}$ & $\begin{array}{l}\text { USE-WEAR } \\
\text { INDICATION }\end{array}$ & PRESUMED USE \\
\hline $\begin{array}{l}\text { Primary } \\
\text { flake }\end{array}$ & B472 & EBA 4 & 175 & $\begin{array}{l}\text { Perpendicular } \\
\text { striation }\end{array}$ & $\begin{array}{l}\text { Scraping soft material, } \\
\text { hides }\end{array}$ \\
\hline $\begin{array}{l}\text { Primary } \\
\text { flake }\end{array}$ & D009 & EBA 5 & 135 & Polish & Cutting soft plant material \\
\hline $\begin{array}{l}\text { Primary } \\
\text { flake }^{\mathrm{a}}\end{array}$ & D009 & EBA 5 & 135 & $\begin{array}{l}\text { Perpendicular } \\
\text { striation }\end{array}$ & Cutting soft plant material \\
\hline $\begin{array}{l}\text { Secondary } \\
\text { flake }\end{array}$ & D009 & EBA 5 & 135 & Polish and rounding & $\begin{array}{l}\text { Scraping soft material, } \\
\text { hides }\end{array}$ \\
\hline $\begin{array}{l}\text { Secondary } \\
\text { flake }\end{array}$ & B353 & EBA 6 & 120 & $\begin{array}{l}\text { Perpendicular } \\
\text { striation and } \\
\text { micro-chipping }\end{array}$ & $\begin{array}{l}\text { Scraping or whittling } \\
\text { medium/hard material }\end{array}$ \\
\hline $\begin{array}{l}\text { Primary } \\
\text { flake }\end{array}$ & A388 & EBA 7 & 110 & Parallel striation & Cutting soft plant material \\
\hline
\end{tabular}

${ }^{\mathrm{a}}$ Same tool as above.

using the northern grasslands for extensive animal herding, coupled with an increase in residential mobility, then there would be a tendency to see smaller settlements presenting greater evidence of processing hides and producing wool fabrics. This does not at all seem to be the case. Animal processing occurred in high proportions in both the largest and smallest settlements. The majority of the tools across the subregion appear to be related to processing animals, though not at the complete exclusion of plant processing.

Early Bronze Age Use-wear Evidence from the Southern Subregion - The largest local community in the southern subregion had a population estimated at around 1750 people. Despite its size, it yielded only two artifacts with evidence of use-wear. These two artifacts are both groundstone knives. The use-wear evidence suggests that they were used for cutting soft plant material such as agricultural grasses.

Table 6. Early Bronze Age Use-Wear Evidence, Southern Subregion

\begin{tabular}{|c|c|c|c|c|c|}
\hline \multirow{4}{*}{ LITHIC TYPE } & \multicolumn{4}{|c|}{ ESTIMATED } & \multirow{4}{*}{ PRESUMED USE } \\
\hline & & LOCAL & MEDIAN LOCAL & & \\
\hline & COLLECTION & COMMUNITY & $\begin{array}{l}\text { COMMUNITY } \\
\text { POPULATION }\end{array}$ & $\begin{array}{l}\text { USE-WEAR } \\
\text { INDICATION }\end{array}$ & \\
\hline & ONII & ID & PUPOLATIUN & INDICAIIN & \\
\hline $\begin{array}{l}\text { Groundstone } \\
\text { knife }\end{array}$ & D137 & EBA 10 & 1750 & Polish & $\begin{array}{l}\text { Cutting soft plant } \\
\text { material }\end{array}$ \\
\hline $\begin{array}{l}\text { Groundstone } \\
\text { knife }\end{array}$ & D125 & EBA 10 & 1750 & Polish & $\begin{array}{l}\text { Cutting soft plant } \\
\text { material }\end{array}$ \\
\hline $\begin{array}{l}\text { Complex } \\
\text { flake }\end{array}$ & A058 & EBA 11 & 300 & Rounding & $\begin{array}{l}\text { Scraping soft } \\
\text { material, hides }\end{array}$ \\
\hline $\begin{array}{l}\text { Groundstone } \\
\text { knife }\end{array}$ & B020 & EBA 12 & 45 & Polish & $\begin{array}{l}\text { Cutting soft plant } \\
\text { material }\end{array}$ \\
\hline
\end{tabular}


Table 7. Use-wear Evidence from Small local Communities, Northern Subregion

\begin{tabular}{|c|c|c|c|c|c|}
\hline LITHIC TYPE & $\begin{array}{c}\text { COLLECTION } \\
\text { UNIT }\end{array}$ & $\begin{array}{c}\text { LOCAL } \\
\text { COMMUNITY } \\
\text { ID }\end{array}$ & $\begin{array}{l}\text { ESTIMATED } \\
\text { MEDIAN LOCAL } \\
\text { COMMUNITY } \\
\text { POPULATION }\end{array}$ & $\begin{array}{l}\text { USE-WEAR } \\
\text { INDICATION }\end{array}$ & PRESUMED USE \\
\hline $\begin{array}{l}\text { Primary } \\
\text { flake }\end{array}$ & B611 & EBA 8 & 30 & $\begin{array}{l}\text { Macroscopic } \\
\text { retouch and } \\
\text { chipping }\end{array}$ & $\begin{array}{l}\text { Cutting soft/medium } \\
\text { wood }\end{array}$ \\
\hline $\begin{array}{l}\text { Secondary } \\
\text { flake }\end{array}$ & B611 & EBA 8 & 30 & $\begin{array}{l}\text { Perpendicular } \\
\text { striation and } \\
\text { polish }\end{array}$ & $\begin{array}{l}\text { Scraping soft material, } \\
\text { hides }\end{array}$ \\
\hline $\begin{array}{l}\text { Secondary } \\
\text { flake }\end{array}$ & B611 & EBA 8 & 30 & $\begin{array}{l}\text { Perpendicular } \\
\text { striation }\end{array}$ & $\begin{array}{l}\text { Scraping soft material, } \\
\text { hides }\end{array}$ \\
\hline $\begin{array}{l}\text { Secondary } \\
\text { flake }\end{array}$ & B611 & EBA 8 & 30 & Diagonal striation & $\begin{array}{l}\text { Cutting soft material, } \\
\text { unclear }\end{array}$ \\
\hline $\begin{array}{l}\text { Secondary } \\
\text { flake }\end{array}$ & B611 & EBA 8 & 30 & Rounding & $\begin{array}{l}\text { Scraping soft material, } \\
\text { hides }\end{array}$ \\
\hline $\begin{array}{l}\text { Secondary } \\
\text { flake }\end{array}$ & B611 & EBA 8 & 30 & $\begin{array}{l}\text { Perpendicular } \\
\text { striation }\end{array}$ & $\begin{array}{l}\text { Scraping soft material, } \\
\text { hides }\end{array}$ \\
\hline $\begin{array}{l}\text { Secondary } \\
\text { flake }\end{array}$ & B611 & EBA 8 & 30 & Rounding & $\begin{array}{l}\text { Scraping soft material, } \\
\text { hides }\end{array}$ \\
\hline $\begin{array}{l}\text { Secondary } \\
\text { flake }\end{array}$ & B345 & EBA 9 & 25 & $\begin{array}{l}\text { Parallel light } \\
\text { striation }\end{array}$ & Cutting soft plant material \\
\hline $\begin{array}{l}\text { Complex } \\
\text { flake }\end{array}$ & B345 & EBA 9 & 25 & $\begin{array}{l}\text { Perpendicular } \\
\text { striation and } \\
\text { micro-chipping }\end{array}$ & $\begin{array}{l}\text { Cutting medium/hard } \\
\text { material: wood, bone }\end{array}$ \\
\hline
\end{tabular}

A medium-sized community of about 300 people just northwest of the large community yielded evidence of scraping animal hides. A much smaller settlement yielded a groundstone knife that has evidence of plant polish on the blade edge.

The tools recovered in the southern subregion and their use-wear evidence suggests more intensive farming may have occurred in the south than in the north. Communities in the southern subregion also engaged in domesticated animal economies. Much like what was seen in the northern subregion, a tendency toward more animal processing in small communities does not seem to be the case (Table 6).

The smallest communities with populations of about five households repeat the pattern of a mixed economy, but again with a trend toward more animal processing in the north (Table 7). There is more evidence of scraping animal hides than any other activity, but other activities are present. The exception is the community labeled EBA (Early Bronze Age) 8; it could be interpreted as a community of specialized herders given the high proportion of scraping activities. However, it should be noted that this type of small specialized community does not characterize the entire survey region nor the northern subregion. Nine other nearby communities indicate a mixed economy.

The sample sizes of stone tools for the Early Bronze Age allow us to recognize with moderate statistical confidence (between 80 and 95\%) that the differences we see in the proportions between the northern and southern regions are real. The statistical confidence has reached the oft-cited $p<0.05$, indicating a significant difference; this level of confidence is meaningful in this context (Cowgill 1977) (Fig. 12, Fig. 13). In concert with the distribution of tools without use-wear, this adds credence to the idea 


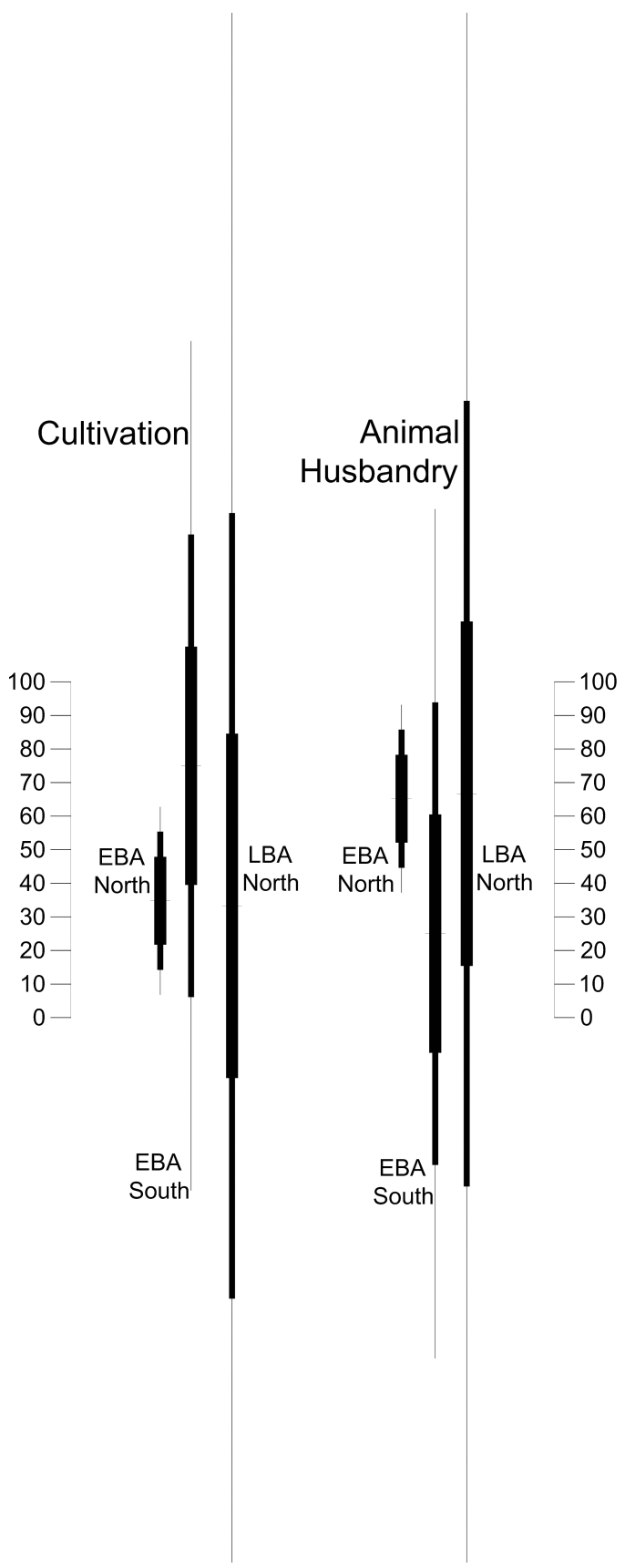

Fig. 12. The proportions of tools related to cultivation and animal husbandry, with confidence bars at $80 \%, 90 \%$, and $95 \%$. 


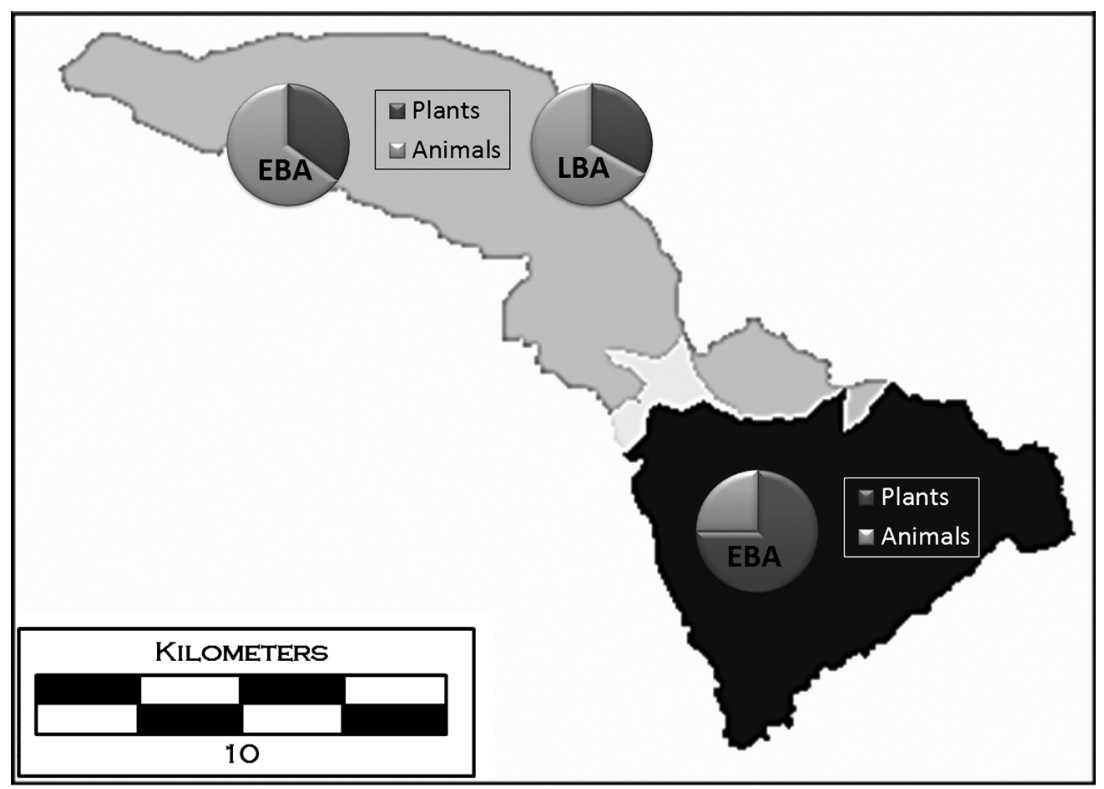

Fig. 13. Proportions of tool types based on use-wear characteristics.

that there were differences in subsistence strategies between the northern and southern subregions during the Early Bronze Age (Fig. 12, Table 8).

Use-Wear Evidence from the Late Bronze Age - The Late Bronze Tuchengzi settlement yielded two tools with evidence of use-wear. About $3.5 \mathrm{~km}$ northwest of this settlement, the only Late Bronze Age groundstone knife was recovered from another settlement of about four to five households (Fig. 13, Table 9). The tools from the Tuchengzi settlement reveal evidence of cutting medium to hard material and soft to medium materials. The use-wear is typical of what one might encounter when a cutting knife frequently comes into contact with bone, but also when it is used to cut soft tissues (Odell and Odell-Vereecken 1980:101).

While the processing of animals was taking place here, the size and scale of the settlement is neither consistent with seasonal mobility (Murdock and Wilson 1972) nor

Table 8. Proportions of Tools Associated with Cultivation and Animal Husbandry

\begin{tabular}{|c|c|c|c|c|}
\hline & \# TOOLS & PLANT & ANIMAL & TOTAL \\
\hline $\begin{array}{l}\text { Early Bronze Age settlements, } \\
\text { northern subregion }\end{array}$ & 23 & $35 \%(8)$ & $65 \%(15)$ & $100 \%$ \\
\hline $\begin{array}{l}\text { Early Bronze Age settlements, } \\
\text { southern subregion }\end{array}$ & 4 & $75 \%(3)$ & $25 \%(1)$ & $100 \%$ \\
\hline Early Bronze Age total & 27 & $41 \%(11)$ & $59 \%(16)$ & $100 \%$ \\
\hline $\begin{array}{l}\text { Late Bronze Age settlements, } \\
\text { northern subregion }\end{array}$ & 3 & $33 \%(1)$ & $67 \%(2)$ & $100 \%$ \\
\hline $\begin{array}{l}\text { Late Bronze Age settlements, } \\
\text { southern subregion }\end{array}$ & 0 & 0 & 0 & 0 \\
\hline Late Bronze Age total & 3 & $33 \%(1)$ & $67 \%(2)$ & $100 \%$ \\
\hline
\end{tabular}


Table 9. Late Bronze Age Use-wear Evidence, Northern Subregion

\begin{tabular}{|c|c|c|c|c|c|}
\hline \multirow{4}{*}{ LITHIC TYPE } & \multicolumn{4}{|c|}{ ESTIMATED } & \multirow{4}{*}{ PRESUMED USE } \\
\hline & & LOCAL & MEDIAN LOCAL & & \\
\hline & COLLECTION & N COMMUNITY & COMMUNITY & USE-WEAR & \\
\hline & UNII & ID & POPULATION & INDICATION & \\
\hline $\begin{array}{l}\text { Secondary } \\
\text { flake }\end{array}$ & B595 & $\begin{array}{l}\text { LBA } 1 \\
\quad \text { (Tuchengzi) }\end{array}$ & 450 & $\begin{array}{l}\text { Striation, micro- } \\
\text { chipping }\end{array}$ & $\begin{array}{l}\text { Cutting medium/hard } \\
\text { material, bone, and flesh }\end{array}$ \\
\hline Complex flake & B595 & $\begin{array}{l}\text { LBA } 1 \\
\quad \text { (Tuchengzi) }\end{array}$ & 450 & $\begin{array}{l}\text { Light striation, } \\
\text { micro-chipping }\end{array}$ & $\begin{array}{l}\text { Cutting soft/medium } \\
\text { material }\end{array}$ \\
\hline $\begin{array}{l}\text { Groundstone } \\
\text { knife }\end{array}$ & A383 & LBA 2 & 25 & Polish & Cutting soft plant material \\
\hline
\end{tabular}

seasonal aggregation, commonly seen with specialized mobile herding (Mearns 1993, 1996). The size and density of the Tuchengzi settlement is too large to be associated with seasonal mobility. Furthermore, if mobility patterns took households out of the survey area for any portion of the year, the same ceramic densities and site sizes would have resulted in even higher population estimates. The final population estimate is based on the average length of time spent accumulating archaeological material. If households sometimes moved outside of the survey area, they would have presumably spread a year's worth of ceramics over multiple areas. That is, when the amount of time in sedentary residence within the survey area is reduced, the population estimate increases. ${ }^{3}$

The sample size for the Late Bronze Age makes it difficult to say with statistical confidence that the use-wear patterns we observe are not just due to the vagaries of sampling (Fig. 12). While it is certain that both animals and plants were being processed in the northern subregion during the Late Bronze Age, it is difficult to say if these activities occured in similar proportions as was seen for the Early Bronze Age (Table 8, Fig. 13). The strongest statement we can say is that the Late Bronze Age proportions from the north do not follow the trend found in the southern subregion during the Early Bronze Age. More important is that all of the proportions indicate mixed plant and animal economies.

\section{Regional Distribution of Subsistence Activities}

There does not appear to be an area or period during the Bronze Age in Zhangwu when agriculture completely disappeared from the range of economic activities. It is clear that mobile herding never completely replaced sedentary agriculture in this region or either of its subregions. However, a pattern suggests a differential use of the landscape during the Bronze Age, especially the Early Bronze Age.

Both the northern and southern parts of the survey area provide evidence of mixed economies. The balance of the mixture varies between the north and south. There is a relatively greater emphasis on animal processing in the northern subregion, while communities in the southern subregion appear to have been relatively more engaged in agricultural activities. It is premature to say if any of these subsistence activities were more intense than the other (Costin 1991), but not knowing opens the door for exciting and interesting future research.

Neither of the two subregions presents evidence of specialization to the degree that might suggest the compulsory complementary relationship between groups of local communities that has been theorized by many scholars (Barfield 2001; Irons 1979; 
Jagchid and Symons 1989; Kazanov 1994). It instead appears that agricultural goods and animal products could be obtained within each local community. Or if people could not obtain such goods and products from their immediate neighbors, they could certainly acquire them from within their sub-regional environmental zone.

\section{CONCLUSIONS}

The evidence points to a mixed subsistence economy that relied on both domesticated plants and animals. The relative proportions of animal vs. plant usage varied as a result of the sub-regional environmental conditions. In the Early Bronze Age, both subregions would have been suitable for farming, although conditions in the southern region made it slightly more favorable. The northern environmental zone consisted of birch forest-steppe, which gave way to heavier birch and oak forest in the south. The topography and higher quality soils in the south made this region more attractive for farming (Williams 2014). In an economy where dry farming is the main form of subsistence (Chifeng 2011:34), the southern part of the survey area would have been especially attractive during the wetter Early Bronze Age. The hilly topography would also have allowed for upland farming during periods of lowland flooding. The flat topography of the northern subregion would have been less attractive for the same reason, but provided ideal conditions for raising greater numbers of animals. The high groundwater table in the north would have caused small springs to appear on the landscape during periods of heavy rainfall (Zheng et al. 2012). These temporary oases would have been a boon to grazing animals and their caretakers.

The type of animal care consistent with the settlement evidence would have involved herding animals during the day or over a few days at distances of up to a few kilometers. The residential pattern of these herders would be sedentism. This is especially consistent with patterns in the Early Bronze Age where regional population densities were 10 times the highest estimates for mobile societies. Ethnographic examples of this type of animal husbandry and settlement pattern show that children do the majority of herding (Fratkin 1989:434; Tenenbaum et al. 2004), allowing adults to carry out farming activities in proximity to villages and farmsteads. Alternatively, specialization at the household level within local communities would also produce the patterns described in this article.

Faunal evidence dated to the Early and Late Bronze Age indicates that pigs were the most common species used in Chifeng (Chifeng 2011). The possibility exists that the economy in Zhangwu involved a mix of raising pigs and farming millet, similar to Chifeng. Classic herd animals may have been a very minor component of the Bronze Age economy. Although there are exceptions (Kohl 2009:97), societies with high degrees of residential mobility seldom raise pigs as a subsistence activity. Sedentary millet farming and pig raising would be consistent with the population densities and tool use-wear patterns from both the Early and Late Bronze Age periods.

By far the most common agricultural product in Northeast China is foxtail millet; it was certainly the most common for at least 5000 years prior to the Bronze Age (Shelach and Mingyu 2013). The use-wear is consistent with foxtail millet as the main agricultural product, although farming other types of grasses remains a possibility. If the main crop is foxtail millet, then its short growing season would have allowed additional resources to be put into the care of animals during the off season.

Many scholars have proposed that climate change (Li et al. 2006; Su and Zhao 2003; Wagner et al. 2011; Wanner et al. 2008; Zhang et al. 2005) brought about large-scale 
economic change that eventually included many local communities (An et al. 2004; Huang et al. 2003; Jin and Liu 2002; Liu and Feng 2012; Wu and Liu 2004; Xiao et al. 2004). In contrast, the results of this research suggest a certain amount of economic resilience during the Bronze Age in the face of changing climatic conditions. While population density was possibly affected by declining agricultural productivity, the climate does not appear to have affected the overall nature of economic practices throughout the region. However, sub-regional environmental conditions clearly influenced economic activities in local communities as long ago as the Early Bronze Age.

There does not appear to have been an increase in extensive herding economies that would have resulted in increased residential mobility by the Late Bronze Age. Instead, the evidence suggests a persistent pattern of plant cultivation mixed with animal husbandry that changes in relative intensity depending on local environmental conditions. Future research would have to be conducted to gather evidence of economic specialization within local communities and resulting social dynamics. The stone tool evidence from Zhangwu does not support the theory of economic transformation across multiple local communities. Such theories might be borne out in other regions, however (DiCosmo 2002; Lattimore 1940; Linduff 1995, 1997; Shelach 1999). For example, evidence from even more marginal environments needs to be investigated to test the notion that this type of economic specialization occurred. The evidence from Northeast China, however, poses problems with the notion that specialized mobile herding is usually tethered to sedentary farming (Lees and Bates 1974). At least in this region of Northeast China during the Bronze Age, economic diversity rather than specialization among local communities appears to have been the strategy used to exploit ecotone or transitional environments.

\section{ACKNOWLEDGMENTS}

This research was made possible by funding from the National Science Foundation and the Center for Comparative Archaeology and Department of Anthropology at the University of Pittsburgh. The Center for Frontier Archaeology at Jilin University and the Liaoning Provincial Institute of Archaeology provided logistical support.

\section{NOTES}

1. The full collection of the use-wear images produced by this project is available in high resolution on the Center for Comparative Archaeology Database, URL: http://www.cadb.pitt.edu/.

2. Researchers following Keeley's (1980) methods propose washing artifacts in mild hydrochloric acid and sodium hydroxide, but other scholars consider this harmful (Plisson and Mauger 1988; Rondon Borras 1990) and Odell (2004:150-151) argues against adopting this as a standard practice.

3. For an extended discussion on the effects of mobility on population estimates, see Williams (2014).

\section{REFERENCES CITED}

An, Chengbang, Zhaodong Feng, and Lingyu Tang

2004 Environmental change and cultural response between 8000 and 4000 cal. yr B.P. in the Western Loess Plateau, Northwest China. Journal of Quaternary Science 19(6):529-535.

BANNING, EDWARD B.

2002 Archaeological Survey. Manuals in Archaeological Method, Theory and Technique. New York: Kluwer Academic/Plenum Publishers. 
BARFIELD, THOMAS

1989 The Perilous Frontier: Nomadic Empires and China. Cambridge, MA: Blackwell.

2001 The shadow empires: Imperial state formation along the Chinese-nomad frontier, in Empires: Perspectives from Archaeology and History: 10-41, ed. S. E. Alcock, T. N. D'Altroy, K. D. Morrison, and C. M. Sinopoli. Cambridge: Cambridge University Press.

BINFORD, LEWIS R.

1973 Interassemblage variability: The Mousterian and the functional argument, in The Explanation of Culture Change: Models in Prehistory: 227-254, ed. Colin Renfrew. Pittsburgh: University of Pittsburgh Press.

Boerma, J.A.K., Luo Guobao, and Huang Biao

1995a People's Republic of China: Reference Soil of Chaoyang County, Typical of the Formerly Wooded, Hilly Areas in the SW Liaoning Province. Soil Brief CN 9. Institute of Soil Science, Academica Sinica, Nanjing and International Soil Reference and Information Center, Wageningen.

1995b People's Republic of China: Reference Soil of the Liaohe Plain, Liaoning Province. Soil Brief CN 10. Institute of Soil Science, Academica Sinica, Nanjing and International Soil Reference and Information Center, Wageningen.

Chifeng International Collaborative Archaeological Research Project

2011 Settlement Patterns in the Chifeng Region. Pittsburgh, PA: University of Pittsburgh Center for Comparative Archaeology.

Clemente, Ignacio, and Juan F. Gibaja

1998 Working processes on cereals: An approach through microwear analysis. Journal of Archaeological Science 25(5):457-464.

Costin, Cathy Lynne

1991 Craft specialization: Issues in defining, documenting, and explaining the organization of production. Archaeological Method and Theory 3:1-56.

Cowgill, George L.

1977 The trouble with significance tests and what we can do about it. American Antiquity 42: 350-368.

DiCosmo, Nicola

1994 Ancient inner Asian nomads: Their economic basis and its significance in Chinese history. Journal of Asian Studies 53(4):1092-1126.

1999 The northern frontier in pre-imperial China, in The Cambridge History of Ancient China: From the Origins of Civilization to 221 B.C.: 885-966, ed. Michael Loewe and Edward L. Shaughnessy. Cambridge: Cambridge University Press.

2002 Ancient China and Its Enemies: The Rise of Nomadic Power in East Asian History. Cambridge: Cambridge University Press.

Drennan, Robert D., C. Adam Berrey, and Christian E. Peterson

2015 Regional Settlement Demography in Archaeology. Clinton Corners, NY: Eliot Werner Publications.

FlanNery, Kent V., ED.

1976 The Early Mesoamerican Village. New York: Academic Press.

Fratkin, ELLIOT

1989 Household variation and gender inequality in Ariaal pastoral production: Results of a stratified time allocation survey. American Anthropologist 91(2):430-440.

Gao Xing and Shen Chen, eds.

2008 Shiqi weihen fenxi de kaogu xue shiyan yanjiu 石器微痕分析的考古学实验研究 [Archaeological Study of Lithic Use-wear Experiments] Beijing: Kexue Chubanshe Science Press.

Huang, Chun Chang, Shichao Zhao, Jiangli Pang, Qunying Zhou, Shue Chen, Pinghua Li, Longjiang MaO, ANd Min Ding

2003 Climatic aridity and the relocations of the Zhou Culture in the southern Loess Plateau of China. Climatic Change 61(3):361-378.

Ibáñez, Juan José, Ignacio Clemente Conte, Bernard Gassin, J. F. Gibaja, J. E. González, B. Márquez, S. Philibert, and A. Rodríguez

2008 Harvesting technology during the Neolithic in South-West Europe. Prehistoric Technology 40: 183-195. 
IRONS, WILLIAM

1979 Political stratification among pastoral nomads, in Pastoral Production and Society: Proceedings of the International Meeting on Nomadic Pastoralism, Paris, 1-3 Dec. 1976: 361-373, ed. Equipe écologie et anthropologie des sociétés pastorales. Cambridge: Cambridge University Press.

Jagchid, Sechin, and Van Jay Symons

1989 Peace, War, and Trade along the Great Wall: Nomadic-Chinese Interaction through Two Millennia. Bloomington: Indiana University Press.

Jin, Guiyun, And Dongsheng Liu

2002 Mid-Holocene climate change in North China, and the effect on cultural development. Chinese Science Bulletin 47(5):408-413.

KaZANOV, ANATOLY

1994 Nomads and The Outside World. Cambridge: Cambridge University Press.

Keeley, LaWrence H.

1980 Experimental Determination of Stone Tool Uses: A Microwear Analysis. Chicago: University of Chicago Press.

KoHL, Phillip L.

2009 The Maikop Singularity: The unequal accumulation of wealth on the Bronze Age Eurasian steppe? in Social Complexity in Prehistoric Eurasia: Monuments, Metals, and Mobility: 91-106, ed. Bryan K. Hanks and Kathryn M. Linduff. Cambridge: Cambridge University Press.

KNUDSON, RUTHANN

1979 Inference and imposition in lithic analysis, in Lithic Use Wear Analysis: 269-282, ed. Brian Haden. New York: Academic Press.

LATTIMORE, OWEN

1940 Inner Asian Frontiers of China. New York: American Geographical Society.

Lees, Susan H., and Daniel G. Bates

1974 The origins of specialized nomadic pastoralism: A systemic model. American Antiquity 39 (2):187-193.

Li, Yiyin, Kathy J. Willis, Liping Zhou, and Haiting Cui

2006 The impact of ancient civilization on the northeastern Chinese landscape: Palaeoecological evidence from the Western Liaohe River Basin, Inner Mongolia. The Holocene 16(8):1109.

LIN, Yun

2002 Bronze vessels of Xia Dynasty found in North China. Research of China's Frontier Archaeology 2002:1-12.

LiNDUFF, KATHERYN M.

1995 Zhukaigou, steppe culture and the rise of Chinese civilization. Antiquity 69(262):133-145.

1997 An archaeological overview, in Ancient Bronzes of the Eastern Eurasian Steppes from the Arthur M. Sackler Collections: 18-98, ed. Emma C. Bunker. New York: Arthur M. Sackler Foundation.

Liu, Fenggui, and Zhaodong Feng

2012 A dramatic climatic transition at $\sim 4000$ cal. yr BP and its cultural responses in Chinese cultural domains. The Holocene 22(10):1181-1197.

LOMBARD, MARLIZE

2006 First impressions of the functions and hafting technology of Still Bay pointed artefacts from Sibudu Cave. Southern African Humanities 18(1):27-41.

MEARns, RoBin

1993 Territoriality and land tenure among Mongolian pastoralists: Variation, continuity and change. Nomadic Peoples 33:73-103.

1996 Community, collective action and common grazing: The case of post-socialist Mongolia. Journal of Development Studies 32(3):297-339.

Murdock, George Peter

1949 Social Structure. New York: Macmillan.

Murdock, George P., and Suzanne F. Wilson

1972 Settlement patterns and community organization: Cross-cultural codes 3. Ethnology 11: 254-295. 
NASH, DAVID T.

1993 Distinguishing stone artifacts from naturefacts created by rockfall processes, in Formation Processes in Archaeological Context: 125-138, ed. Paul Goldberg, David T. Nash, and Michael D. Petraglia. Madison: Prehistory Press.

Nelson, Sarah M.

1993 The Archaeology of Korea. Cambridge: Cambridge University Press.

Nelson, Sarah M., ed.

1995 The Archaeology of Northeast China. London: Routledge.

Odell, George

2004 Lithic Analysis. New York: Kluwer Academic/Plenum.

Odell, George H., and Frieda Odell-Vereecken

1980 Verifying the reliability of lithic use-wear assessments by "blind tests": The low-power approach. Journal of Field Archaeology 9:87-120.

Peterson, Christian E., and Robert D. Drennan

2005 Communities, settlements, sites, and survey: Regional-scale analysis of Prehistoric human interaction. American Antiquity 70(1):5-30.

Plisson, Hugues, and Manuelle Mauger

1988 Chemical and mechanical alteration of microwear polishes: An experimental approach. Helinium 28(1):3-16.

Rondon Borras, Teresa

1990 Chemical process of cleaning in microwear studies: Conditions and limits of attack: Application to archaeological sites, in The Interpretive Possibilities of Microwear Studies: Proceedings of the International Conference on Lithic Use-wear Analysis, 15-17 February 1989, Uppsala, Sweden: 179-184, ed. B. Gräslund, H. Knuttson, K. Knuttson, and J. Taffinder, AUN 14. Uppsala: Societas Archaeologica Uppsalensis.

SHELACH, GideON

1999 Leadership Strategies, Economic Activity, and Interregional Interaction: Social Complexity in Northeast China. New York: Kluwer Academic/Plenum.

2009 Prehistoric Societies on the Northern Frontiers of China: Archaeological Perspectives on Identity Formation and Economic Change during the First Millennium B.C.E. London: Equinox Publishers.

Shelach, Gideon, and Teng Mingyu

2013 Earlier Neolithic economic and social systems of the Liao River region, Northeast China, in A Companion to Chinese Archaeology: 37-54, ed. Anne Underhill. Cambridge, MA: Blackwell Malden.

Smallwood, Ashley Michelle

2006 Use-Wear Analysis of the Clovis Biface Collection from the Gault Site in Central Texas. Unpublished Masters Thesis. Department of Anthropology, Texas A\&M University.

Su, Yongzhong, and Halin ZhaO

2003 Soil properties and plant species in an age sequence of Caragana microphylla plantations in the Horqin Sandy Land, North China. Ecological Engineering 20(3):223-235.

Tarasov, Pavel, Guiyun Jin, and Mayke Wagner

2006 Mid-Holocene environmental and human dynamics in northeastern China reconstructed from pollen and archaeological data. Palaeogeography, Palaeoclimatology, Palaeoecology 241(2):284-300.

Tenenbaum, Harriet R., Paloma Visscher, Francisco Pons, and Paul L. Harris

2004 Emotional understanding in Quechua children from an agro-pastoralist village. International Journal of Behavioral Development 28(5):471-478.

Wagner, Mayke, Pavel Tarasov, Dominic Hosner, Andreas Fleck, Richard Ehrich, Xiaocheng Chen, AND Christian Leipe

2013 Mapping of the spatial and temporal distribution of archaeological sites of northern China during the Neolithic and Bronze Age. Quaternary International 290-291:344-357.

Wagner, Mayke, Xinhua Wu, Pavel Tarasov, Ailjiang Aisha, Christopher Bronk Ramsey, Michael Schultz, Tyede Schmidt-Schultz, and Julia Gresky

2011 Radiocarbon-dated archaeological record of early first millennium B.C. mounted pastoralists in the Kunlun Mountains, China. Proceedings of the National Academy of Sciences 108(38):1573315738. 


\section{WANG LIXIN 王立新}

2004 Liaoxi qu Xia zhi Zhanguo shiqi wenhua geju yu jingji xingtai de yanjin 辽西区夏至战国时 期文化格局与经济形态的演进 [The evolution of cultural pattern and economic formation in the Western Liaoning area from the Xia to the Warring States period]. Kaogu Xuebao 2004 (3):243-270.

2007 Shanqian yizhi fajue ziliao suo fanying de Xiajiadian xia ceng wenhua jingji xingtai yu huanjing beijing 山前遗址发掘资料所反映的夏家店下层文化的经济形态与环境背景 [The economic pattern and environmental context of Lower Xiajiadian culture reflected by the excavation data of Dashanqian Site]. Bianjiang Kaogu Yanjiu 2007(6):350-357.

2013 The lower Xiajiadian culture of the Western Liao drainage system, in A New Companion for Chinese Archaeology: 81-102, ed. Anne Underhill. Malden: Blackwell.

Wanner, Heinz, Jürg Beer, Jonathan Bütikofer, Thomas J. Crowley, Ulrich Cubasch, Jacqueline Flückiger, Hugues Goosse, Martin Grosjean, Fortunat Joos, Jed O. Kaplan, Marcel Küttel, Simon A. Müller, I. Colin Prentice, Olga Solomina, Thomas F. Stocker, Pavel Tarasov, Mayke Wagner, AND MARTIN WIDMANN

2008 Mid- to late holocene climate change: An overview. Quaternary Science Reviews 27 (19-20):1791-1828.

Williams, James T.

2014 Staple Economies Social Integration in Northeast China: Regional Organization in Zhangwu, Liaoning, China. Unpublished diss. Department of Anthropology, University of Pittsburgh.

2015 Demography and conflict during the Warring States and Han Periods in Northern Liaoning. Asian Archaeology 3:1-10.

Wu, WenXiang, and Tungsheng Liu

2004 Possible role of the "Holocene Event 3" on the collapse of Neolithic Cultures around the Central Plain of China. Quaternary International 117(1):153-166.

Xiao, Jule, Qinghai Xu, Toshio Nakamura, Xiaolan Yang, Wendong Liang, and Yoshio Inouchi 2004 Holocene vegetation variation in the Daihai Lake region of north-central China: A direct indication of the Asian monsoon climatic history. Quaternary Science Reviews 23(14):1669-1679.

Zhang, Jiyi, Halin Zhao, Tonghui Zhang, Xueyong Zhao, and Sam Drake

2005 Community succession along a chronosequence of vegetation restoration on sand dunes in Horqin Sandy Land. Journal of Arid Environments 62(4):555-566.

Zheng, Xiao, Zhu Jiajunn, Yan Qiaoling, and Song Lining

2012 Effects of land use changes on the groundwater table and the decline of Pinus sylvestris var. mongolica plantations in southern Horqin Sandy Land, Northeast China. Agricultural Water Management 109:94-106. 